\title{
Characterization of Bioactive Compounds in Fruit and Vegetable Bagasse
}

\author{
Fernanda dos Santos Cardoso ${ }^{1^{*}}$, Ingrid Lessa Leal ${ }^{1}$, Tatiana Barreto Rocha Nery ${ }^{1}$ \\ ${ }^{1}$ Senai Cimatec University Center; Salvador, Bahia, Brazil
}

\begin{abstract}
The use of agro-industrial residues is presented in food waste. The processing of them is an opportunity for the development of by-products, as well as the aggregation of lost value, and the sustainable use of these residues. The study aimed to characterize the bioactive compounds in grape, carrot, cocoa, and banana skins from the processing of juice, banana chips, and chocolate. The analyzed samples showed good moisture, satisfactory water activity value, with the highest flavonoid content in the grape sample (1.679 $\mathrm{mg} \mathrm{EQ} / \mathrm{g}$ ) and the highest phenolic content in the cocoa epicarp sample (1.367 $\mathrm{mg}$ EAG/g). In this way, we verified the viability of using food peels in the food industry, enabling the use of waste generated. Keywords: Food Waste. By-products. Bioactive Compounds.
\end{abstract}

\section{Introduction}

The Food and Agriculture Organization of the United Nations - FAO, estimates that the world production of agro-industrial residues reaches 1.3 billion tons per year, since $1 / 3$ of the food potentially destined for human consumption is wasted, either as residues, from processing or as a loss in the production chain [1].

The residues generated by the juice industry, fruit peels, and seeds can represent a loss of biomass and nutrients, in addition to the inadequate disposal causing the pollution of soils and water bodies, causing potential public health problems [2].

Studies show that these residues contain few calories, are a source of micronutrients, fiber and are rich in phenolic compounds and flavonoids in large amounts. These compounds can reduce the risk of cardiovasculardisease and some cancers [3] . The use of agro-industrial residues, especially fruit peels and seeds, is an opportunity for the development of by-products, aggregation of lost value, and sustainable use of these residues [4].

Received on 11 March 2021; revised 17 May 2021.

Address for correspondence: Fernanda dos Santos Cardoso. Av. Orlando Gomes, 1845 - Piatã, Salvador - BA- Brazil. Zipcode: 41650-010. E-mail: fernandacardoso113@gmail. com. Article selected from VI SENAI CIMATEC Scientific and Technological Research Evaluation Seminar - 2021.

J Bioeng. Tech. Appl. Health

2021;4(2):58-62.

(C) 2021 by SENAI CIMATEC. All rights reserved.
Thus, investigating as a way to minimize this disposal, aiming to know the nutritional quality of by-products generated by food processing industries located in Bahia, such as grape and carrot bagasse from the company PUDJA, mesocarp and cocoa epicarp from the company Mais do Cocoa, and banana peel from Bioalimentos land, this work aimed to analyze the proximate composition and quantify phenolic compounds and flavonoids from fruit residues from different processes.

\section{Material and Methods}

The systematic review selected keywords such as bioactive compounds, phenolics, flavonoids, and related terms. The research focused on the period from 2020 to 2021.

The techniques used to perform the characterization of bioactive compounds were following the literature $[5,6]$.

We received the bioactive compounds in fruit and vegetable peels (grape, carrot, cocoa, and banana peel), by the Bionutrition Laboratory of SENAI CIMATEC. They went through the milling process and stored in vacuum packaging until the moment of analysis. We collected the moisture and water activity of these products. The physical-chemical assessment was carried out concerning moisture content, using an infrared moisture balance (MOC-120H; Shimadzu), and concerning water activity, we used a decagon (Novasina, Lab Master aw). 
For the analysis of bioactive compounds, extraction was performed by diluting the samples (flour) in $80 \%$ cereal alcohol. Afterward, filtration was performed in previously tared vials and the samples were dried in a concentrator (Genevac, DUC 22060 - N00). To prepare the mother solution, the dry material was dissolved with grain alcohol and then the solutions were stored under refrigeration for 24 hours.

The content of total phenolic compounds was determined based on the methodology proposed in the literature by using the sample's mother solution, aqueous folin solution, and sodium carbonate [5]. The absorbance evaluation was performed in a spectrophotometer (Femto, 600 plus) with a wavelength of $765 \mathrm{~nm}$.

The quantifying of total flavonoids was performed according to the methodology described by Meda A. [6]. The origin solution of each sample and the methanolic aluminum chloride solution were used. Absorbance reading was performed using a spectrophotometer (Femto, 600 plus), with a wavelength of $415 \mathrm{~nm}$.

\section{Results and Discussion}

We observed that the carrot peel had the highest moisture value, while the banana peel had the lowest value. Besides, the results are within the standards required by RDC 263/2005 and establish a maximum moisture content of $15 \%$ for flour obtained from fruits and seeds [7].
The results also showed low water activity for all analyzed bark samples, indicating values ranging between 0.389 and 0.426 . So, we inferred that the flours used have satisfactory water activity since for the development of bacteria pathogens the value found must exceed 0.854 [8].

The phenolic compounds in a plant contribute to the growth and reproduction of vegetables. In food, they are responsible for the color and aroma, whereas, for humans, the consumption of foods rich in phenolic compounds reduces the risk of developing pathologies such as arteriosclerosis and cancer [9].

We found that the Epicarp of cocoa $(1.367 \mathrm{mg}$ EAG/g) and the Mesocarp of cocoa $(1.088 \mathrm{mg}$ EAG/g) were the husks that presented the highest levels of phenolic compounds. The carrot husks $(0.310 \mathrm{mg}$ EAG/g) g) and banana $(0.638 \mathrm{mg}$ EAG/g) had both the lowest levels, but still within the average established in the gallic acid behavior graph, which is 0.124 to $2.122 \mathrm{mg} \mathrm{EAG/g}$ (Table 1 and Figure 1) [7].

Flavonoids are bioactive compounds that can be found in many foods. In plants, it helps to protect against microorganisms and defend against the incidence of ultraviolet rays. In humans, the consumption of foods rich in flavonoids favors antioxidant reactions which act positively to delay aging and prevent inflammatory reactions, in addition to other benefits [10].

The samples showed that the highest levels of flavonoids found were from grape skins (1.679 $\mathrm{mg} \mathrm{EQ} / \mathrm{g}$ ) and banana (0.640 $\mathrm{mg} \mathrm{EQ/g),} \mathrm{while} \mathrm{the}$

Table 1. Collected data in the phenolic test.

\begin{tabular}{cccccc}
\hline[] $\boldsymbol{\mu} / \mathbf{m L}$ (EAG) & ABS & ABS & ABS & Average & Standard deviation \\
\hline 10 & 0.124 & 0.123 & 0.124 & 0.124 & 0.000 \\
25 & 0.316 & 0.321 & 0.320 & 0.319 & 0.002 \\
50 & 0.631 & 0.625 & 0.65 & 0.635 & 0.011 \\
100 & 1.143 & 1.161 & 1.155 & 1.153 & 0.007 \\
150 & 1.640 & 1.636 & 1.636 & 1.637 & 0.002 \\
200 & 2.092 & 2.125 & 2.149 & 2.122 & 0.023 \\
\hline
\end{tabular}

Carbonate: Anhydrol Folin: Exodus 
Figure 1. Gallic acid behavior graph.

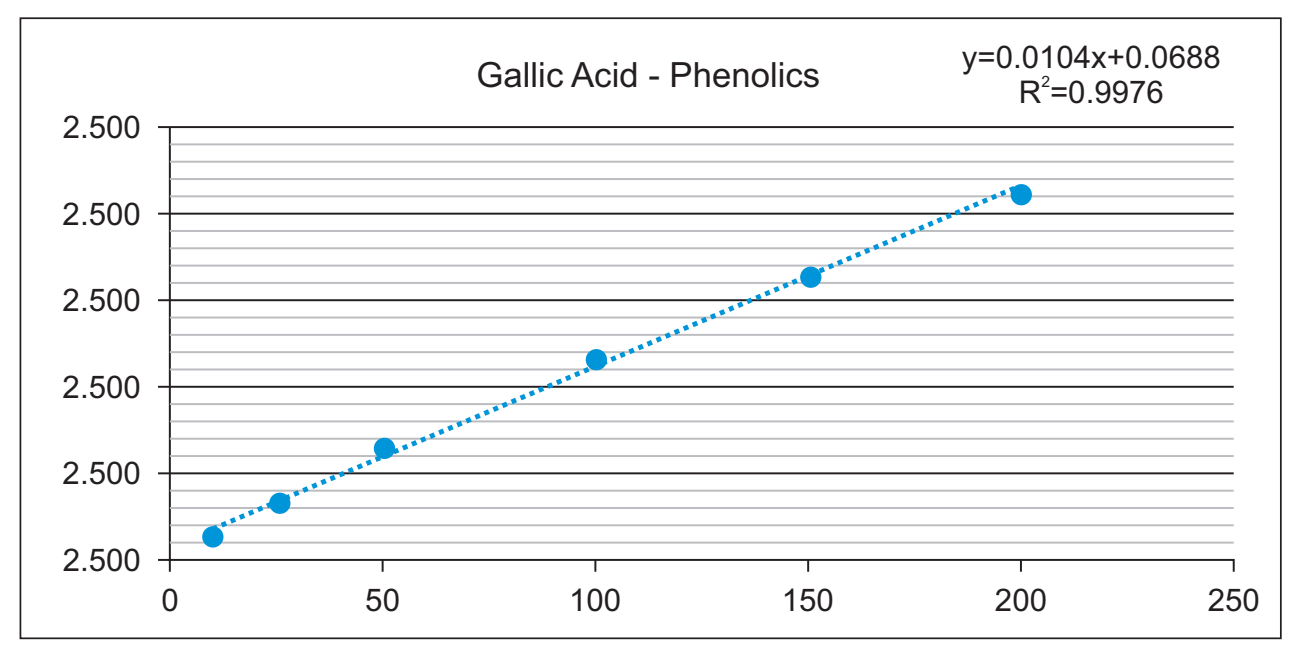

lowest levels were from carrot skins $(0.253 \mathrm{mg}$ $\mathrm{EQ} / \mathrm{g}$ ) and mesocarp cocoa (0.320 mg EQ/g). They are within the mean variation established in the quercetin graph, which ranges from 0.037 to 1.859 $\mathrm{mg} \mathrm{EQ} / \mathrm{g}$ (Table 2 and Figure 2)[9].

Table 3 presents the values of the physicochemical characterization of the samples of grape and carrot bagasse, cocoa mesocarp and epicarp, and banana peel.

\section{Conclusion}

The samples analyzed presented good moisture, satisfactory water activity, and phenolic compounds and flavonoids within the average. Bananas stand out as having lower moisture and water activity, carrots with higher moisture but fewer phenolics and flavonoids, cocoa mesocarp with higher water activity, cocoa epicarp with higher phenolic content, and grape with the highest flavonoid content. Thus, the feasibility of using food peels in the food industry is reported in the study through enabling a waste reduction, helping to strengthen the immune system, and using the waste generated by food processing companies.

\section{Acknowledgments}

We thank the advisor Tatiana Barreto Rocha Nery for all her support throughout the development of my project. We would like also to thank the CNPq research institution and the Senai Cimatec University Center.

Table 2. Collected data in the flavonoid test.

\begin{tabular}{cccccc}
\hline [ ] $\boldsymbol{\mu g} / \mathbf{m L}(\mathbf{E Q})$ & Abs 01 & Abs 02 & Abs 03 & Average & Standard deviation \\
\hline 1 & 0.034 & 0.043 & 0.034 & 0.037 & 0.004 \\
15 & 0.499 & 0.498 & 0.491 & 0.496 & 0.004 \\
30 & 0.963 & 0.979 & 0.991 & 0.978 & 0.011 \\
45 & 1.461 & 1.452 & 1.451 & 1.455 & 0.004 \\
60 & 1.863 & 1.854 & 1.86 & 1.859 & 0.004 \\
75 & 2.179 & 2.16 & 2.166 & 2.168 & 0.008 \\
\hline
\end{tabular}

Chloride: Vetec Methanol: Anhydrol 
Figure 2. Quercetin behavior graph.

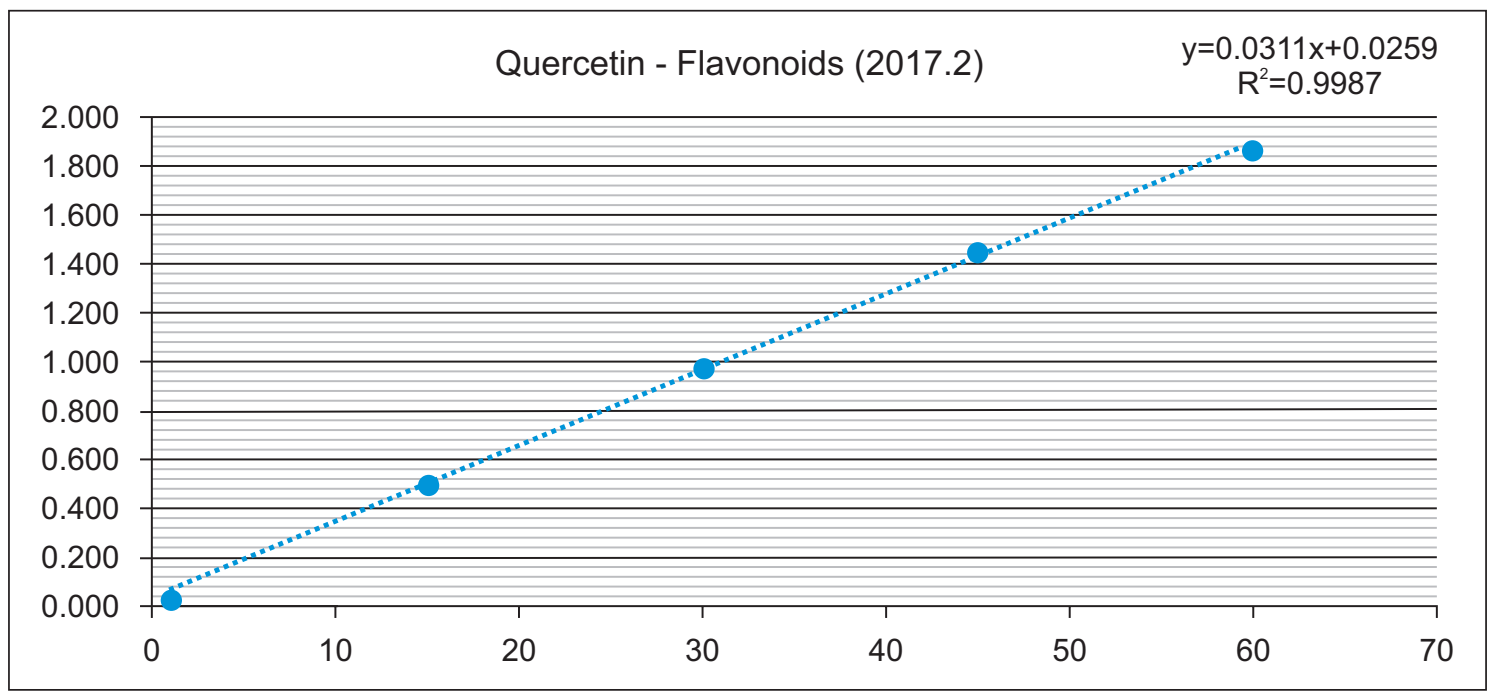

Table 3. Physicochemical characterization, bioactive compounds from fruit and vegetable bagasse.

\begin{tabular}{cccccc}
\hline Tests & Grape & Carrot & Cocoa mesocarp & Cocoa epicarp & Banana \\
\hline $\begin{array}{c}\text { Moisture } \\
(\%)\end{array}$ & $10.42 \pm 0.14$ & $12.96 \pm 0.24$ & $9.17 \pm 1.02$ & $10.07 \pm 0.41$ & $3.33 \pm 0.96$ \\
$\begin{array}{c}\text { Water } \\
\text { activity }\end{array}$ & $0.390 \pm 0.01$ & $0.403 \pm 0.01$ & $0.426 \pm 0.03$ & $0.396 \pm 0.01$ & $0.389 \pm 0.01$ \\
$\begin{array}{c}\text { Total } \\
\text { phenolics }\end{array}$ & $0.679 \pm 0.68$ & $0.310 \pm 0.03$ & $1.088 \pm 0.01$ & $1.367 \pm 0.05$ & $0.638 \pm 0.04$ \\
$\begin{array}{c}\text { (mg EAG/g) } \\
\text { Flavonoids } \\
(\text { mg EQ/g) }\end{array}$ & $1.679 \pm 0.06$ & $0.253 \pm 0.03$ & $0.320 \pm 0.11$ & $0.521 \pm 0.03$ & $0.640 \pm 0.03$ \\
\hline
\end{tabular}

EAG: equivalent in gallic acid; EQ: Quercetin equivalent.

\section{References}

1. FAO. Desperdício de alimentos tem consequências no clima, na água, na terra e na biodiversidade.

2. Rosa MF et al. Valorização de resíduos da agroindústria. II Simpósio Internacional sobre Gerenciamento de Resíduos Agropecuários e Agroindustriais - II SIGERA 15 a 17 de março de 2011 - Foz do Iguaçu, PR Volume I - Palestras.

3. Constante PJ et al. Fatores associados ao consumo de frutas e hortaliças no Brasil. São Paulo: Revista Saúde Pública 2009;43(2).

4. Cabral. Umberlândia. 10,3 milhões de pessoas moram em domicílios com insegurança alimentar grave. IBGE. Rio de Janeiro: 2020.

5. Singleton VL et al. Analysis of total phenols and other oxidation substrates and antioxidants by means of folin-ciocalteu reagent. Methods in Enzymology 1999;299:152-178.

6. Lamien-Meda A et al. Determination of the total phenolic,flavonoid and proline Contents in Burkina Fasan Honey, as well as their radical scavenging activity. 2005.

7. Bwnder $\mathrm{ABB}$ et al. Obtenção e caracterização de farinha de casca de uva e sua utilização em snack extrusado. Campinas: Braz. J. Food Technol. 2016;19. 
8. Ditchfield C. Estudo dos métodos para a medida da atividade de água. São Paulo, 2000.

9. Angelo PM, Jorge N. Compostos fenólicos em alimentos - uma breve revisão. São Paulo: Rev. Inst. Adolfo Lutz 2007;66(1).
10. Machado $\mathrm{H}$ et al. Flavonóides e seu potencial terapêutico. Juiz de Fora: Boletim do Centro de Biologia da Reprodução 2008;27(1/2):33-39. 